\title{
Appraising the effects of atmospheric aerosols and ground particulates concentrations on GPS-derived PWV estimates
}

\author{
Yahaya A. Aliyu ${ }^{\mathrm{a}, \mathrm{c}, *}$, Joel O. Botai ${ }^{\mathrm{b}, \mathrm{a}}$ \\ ${ }^{a}$ Department of Geography, Geoinformatics and Meteorology, University of Pretoria, Pretoria, 0002, South \\ Africa \\ b South African Weather Service, 442 Rigel Avenue South, Erasmusrand, Pretoria, 0001, South Africa \\ ${ }^{c}$ Department of Geomatics, Ahmadu Bello University, Zaria, Kaduna, 810282, Nigeria \\ * Corresponding author. Department of Geography, Geoinformatics and Meteorology, University of Pretoria, \\ Pretoria, 0002, South Africa. E-mail address: u15221408@tuks.co.za (Y.A. Aliyu).
}

\section{Highlights}

- Mitigating aerosol/particulate pollution in a Nigerian city.

- CW-HAT200 particulate counter is validated.

- Significant relationship between GPSPwv and aerosols/particulates.

- New mechanism for GPS PwV $^{-}$PM$_{10}$ relationship.

\begin{abstract}
In 2016, three Nigerian cities were listed amongst the World's most polluted in terms of particulate matter (PM). Acknowledging Nigeria's limited resources for outdoor air pollution monitoring, this study attempts to investigate the effects on atmospheric aerosol optical depth and ground PM on GPS derived-precipitable water vapour estimates. The study utilized available GPSderived precipitable water vapour $\left(\mathrm{GPS} \mathrm{SWv}_{\mathrm{PW}}\right.$ ), the moderate resolution imaging spectroradiometer aerosol optical depth (MODIS $\mathrm{AOD}_{\text {) }}$ and the ground level particulate matter of less than 10 microns (GPM) datasets for December 2015 - November 2016. All the datasets were tested for normality. To

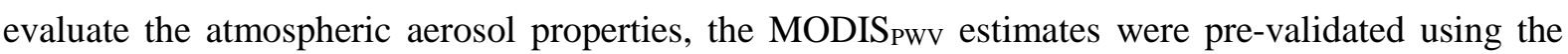
GPS $_{\text {PWv }}$ measurements. The results revealed GPS Pwv-MODIS $_{\text {Pwv }}$ agreement $(\mathrm{R}=0.964$; RMSE $=$ $3.810 \mathrm{~mm})$. The $\mathrm{GPS}_{\mathrm{PWV}}-\mathrm{MODIS}_{\mathrm{AOD}}$ analysis showed relationship $(\mathrm{R} \leq-0.636$; RMSE $\leq 0.563)$ for the

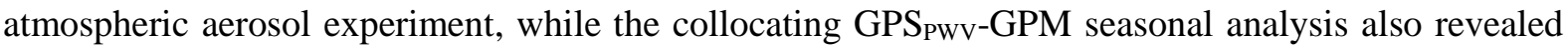
significant correlation $(\mathrm{R}<-0.660)$. The correlation of combined seasonal datasets for the $\mathrm{GPS}_{\mathrm{PWV}}-$

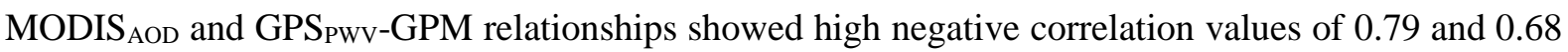
respectively. The findings of this study is in agreement with similar related studies, as well as serve as future position accuracy for similar related studies.
\end{abstract}

Keywords: GPS PWV; MODIS AOD; Particulate Matter PM10; Nigeria

\section{Introduction}

Atmospheric water vapour plays a crucial role in the Earth's climate system as well as the monitoring of aerosols/particulate properties (Solomon et al., 2010; Zhang et al., 2017). Despite its importance to a wide range of spatial and temporal atmospheric processes, it is one of the poorly understood components of the Earth's atmosphere (Boutiouta and Lahcene, 2013). Observational studies have 
reported that the intensity of aerosol particles contributes to climatic variables such as precipitation of liquid water and electrification of thunderstorms (Middey and Chaudhuri, 2013; Zhao et al., 2016). The significance of atmospheric studies for aerosol/water vapour projections has attracted earth observation satellites and global positioning system (GPS) approaches (Nordio et al., 2013; Ortiz de Galisteo et al., 2014).

Scientists have since embraced the concept of GPS meteorology as it provides the ability to measure atmospheric water vapour content for application in diverse topics such as atmospheric chemistry and global climate change (Bevis et al., 1992). GPS offers consistent and precise atmospheric information for precise-point positioning (PPP), ionospheric/tropospheric studies and general environmental assessments that can be used for sensing atmospheric water vapour contents (Zumberge et al., 1997). The GPS signals recorded using ground level continuous operating reference station (CORS), are usually subjected to various attenuations such as, multipath, ionosphere/troposphere delay and signal strength fluctuations. Some of these signal attenuations are presently being assimilated into models for aerosol evaluation.

Since the introduction of the space-based pollution monitoring instruments in the mid-90s, the instruments have continued to display increased user-friendly proficiency for atmospheric processes estimations in 4-dimensional resolution (Duncan et al., 2014; Tsay et al., 2016). Aerosols (particulates) are a composite combination of suspended solid and liquid elements (excluding cloud units) that are being monitored using satellite-based instruments (Gupta et al., 2006). They are an essential component of the climate system and a major concern of the earth's existing anthropogenic radiative force. To minimize these concerns, precise and regular appraisal of these aerosols distributions are necessary so as to regulate its negative impact on man's environment. Accurate monitoring of atmospheric processes such as aerosols and trace gases, are also vital for developing efficient local, regional or global climate models (Madrigano et al., 2013; Chew et al., 2016).

Air pollution remains a serious environmental challenge in many developing countries (Lau and He, 2017). Nigeria accommodates Africa's largest sophisticated population, many of whom continue to migrate to the high-density settlements that surround the urban cities. Three of its developing cities (Onitsha, Kaduna and Aba) were listed amongst the World's top ten most polluted cities (Figure 1), in terms of particulate matter of less than 10 microns (WHO, 2016). Nigeria is reported to have five air monitoring stations established by the Nigerian Meteorological Agency (NiMET) (UNEP, 2015), their operational status remains sceptical as the review of literature showed that there is no record of their data being utilized. 


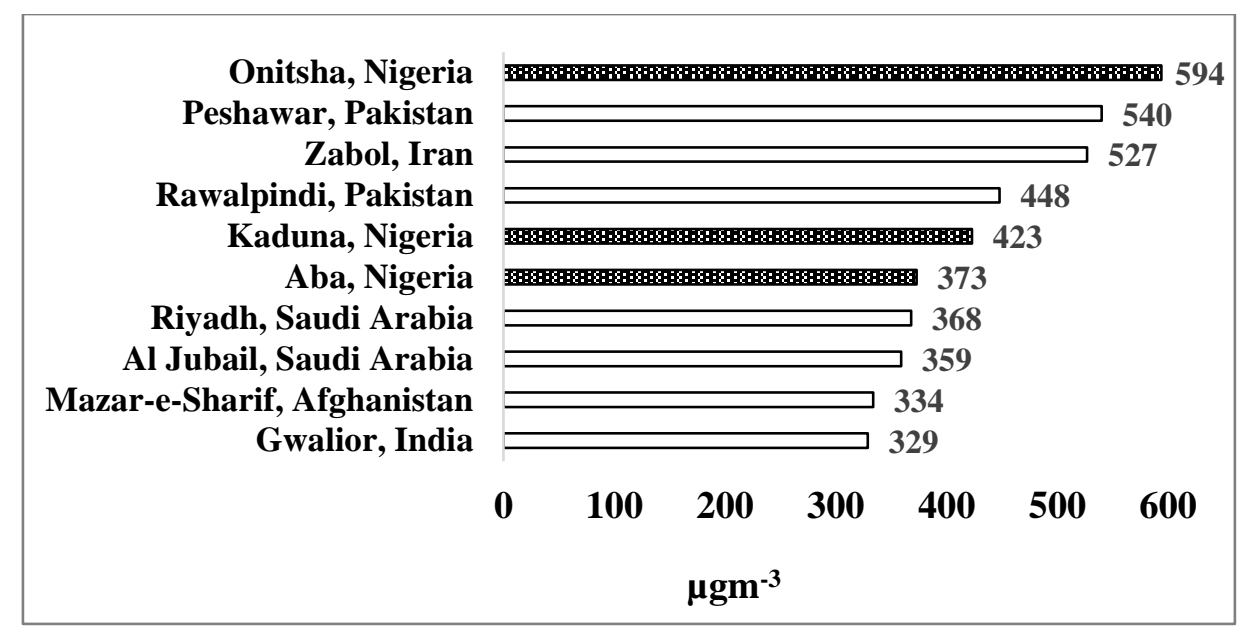

Figure 1. The World's 10 most polluted cities in terms of particulates less than 10 microns, modified after the (WHO, 2016). Shaded column highlight the Nigerian cities.

Satellite-based observations provide a comprehensive view of the earth's atmosphere (Streets et al., 2013) and serves as a practical means for the retrieval of both water vapour and aerosol estimates in a limited resources environment like Nigeria. If the precision and legitimacy of satellite-based estimates are to be verified, the availability of ground-based pollution network/dataset is crucial. Ground-based GNSS operates a meteorological technique whereby its signal delays can be used to derive PWV estimates (Boutiouta and Lahcene, 2013). GNSS remote sensing is becoming necessary due to the technical improvements applied to their inexpensive processing and easy-access of weather insensitive signals (Bonafoni and Biondi, 2016).

It is important for a country like Nigeria to exploit available resources for mitigating particulate air pollution. It is on this basis that this study utilizes seasonal variability of input parameters; GPSderived precipitable water vapour, MODIS AOD estimates and ground PM measurements, to appraise the effect of atmospheric aerosols and ground particulates concentrations on GPS derived PWV estimates. This study plans to direct a latent position for Nigeria, on the practicability of its existing Nigerian global navigational satellite system reference network (NIGNET) for ground particulates and atmospheric aerosols monitoring. The data processing techniques are described as follows.

\section{Methodology}

\subsection{Study Area}

Nigeria established a GNSS Reference Network (NIGNET) through a joint collaboration between Nigeria's Office of the Surveyor General of the Federation (OSGOF) and the Africa Reference Frame (AFREF) programme (Ayorinde et al., 2016). The ABUZ station was utilized for the extraction of the GPS PWV estimates (Figure 2). The ABUZ station is hosted in the main campus of the Ahmadu Bello University Zaria, northern Nigeria. The climate within the study area is categorized into dry (October- 
May) and wet (June-September) seasons. It is further characterized by the peak low temperature (14.1 $\left.{ }^{\circ} \mathrm{C}\right)$ during the harmattan in January and the peak high temperature $\left(35.2{ }^{\circ} \mathrm{C}\right)$ in April. The ABUZ Continuous Operating Reference Station (CORS) is a Trimble NETR8 receiver type with antenna TRM59800.00. The system(s) of observations are GPS and GLONASS. The vertical antenna height specification is $0.17 \mathrm{~m}$. The ABUZ station utilized in this study was adopted for two reasons. First, it is the only study location with collocating time-series atmospheric and ground particulates (aerosols) measurements, to achieve the study objectives. Secondly, Abbasy et al., (2017) have endorsed the practicability of utilizing a single GPS station for meteorological studies. The meteorological parameters (surface temperature and pressure) required for the ABUZ GPS derived PWV estimates were synchronized with an existing automatic weather observing station (AWOS). The derived PWV were extracted from GPS data obtained in Receiver Independent Exchange (RINEX) format. The ABUZ RINEX observation sampling frequency is 30 secs, and was accessed via NIGNET portal (http://www.nignet.net/data/RINEX).

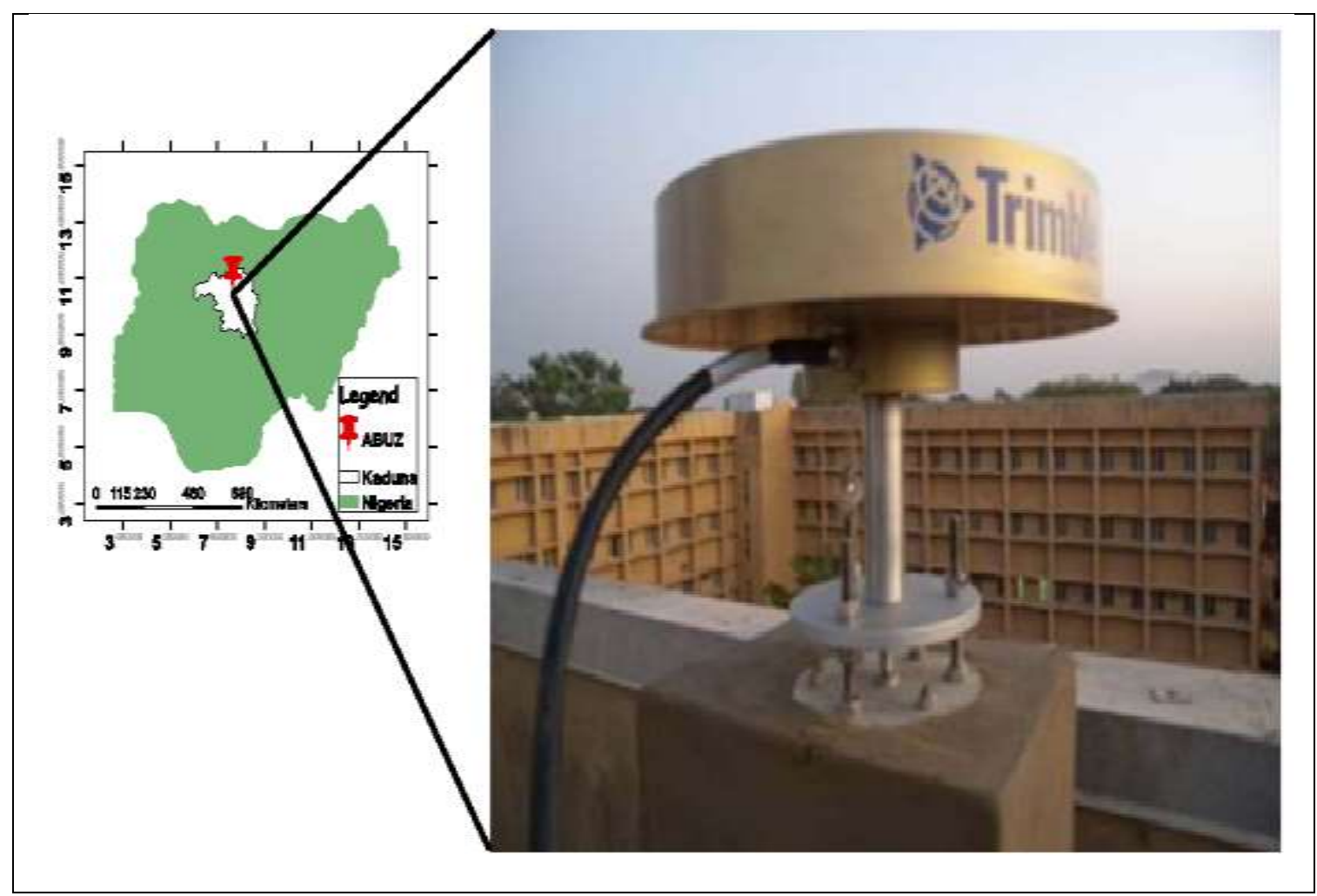

Figure 2. The ABUZ NIGNET station situated within the Ahmadu Bello University Main Campus, Zaria Nigeria from which precipitable water vapor (PWV) will be extracted for this study

\subsection{GPS PWV Estimates}

To extract the PWV estimates for precise-point positioning (PPP), the GPS RINEX observation data was processed using WaSoft GNSS software designed by Wanninger (2000) and validated by Schröder et al. (2017). We utilized International GNSS service (IGS) final paths and earth revolution 
parameters for tropospheric delay derivation and antenna phase centre offsets. Satellite elevation mask of 10 degrees was adopted (Kouba, 2009). The Saastamoinen model (1972) plus random-walk mechanism from meteorologically sourced global pressure and temperature (GPT) model was employed as a priori tropospheric model while the zenith delay was processed via the Vienna mapping function (VMF) (Boehm et al., 2006). The WaSoft software is capable of determining the three dimensional data as well as tropospheric factors, which incorporates the Zenith Tropospheric Delay (ZTD).

We transferred atmospheric temperature and pressure to the ABUZ station from the nearby meteorological (AWOS) station using Equation [1] (Bai and Feng, 2003; Musa et al., 2011). We took into consideration the horizontal distance and observation height between the GPS and AWOS station (Table 1).

$$
\left.\begin{array}{l}
T_{G N S S}=T_{M S L}-0.0065 \times H_{G N S S} \\
P_{G N S S}=P_{M S L}\left(1-0.0000226 \times H_{G N S S}\right)^{5.225}
\end{array}\right\}
$$

Where $\mathrm{T}_{\mathrm{GNSS}} ; \mathrm{P}_{\mathrm{GNSS}}$ are the respective reduced temperature and pressure at the $\mathrm{ABUZ}$ station of interest, $\mathrm{T}_{\mathrm{MSL}} ; \mathrm{P}_{\mathrm{MSL}}$ are the respective temperature and pressure values at the automatic weather observing station (AWOS) mean seal level. The Equation (1) takes into consideration, possible variability in the sensitivity of temperature and pressure at the GNSS antenna height, $\mathrm{H}_{\mathrm{GNSS}}$.

Table 1. Properties of the ABUZ station and the matching AWOS station from which meteorological parameters were interpolated to the actual station level (modified after Isioye et al., 2017)

\begin{tabular}{|c|c|c|c|c|c|c|c|c|}
\hline \multirow{2}{*}{$\begin{array}{l}\text { GNSS } \\
\text { Station }\end{array}$} & \multicolumn{2}{|c|}{$\begin{array}{l}\text { GNSS station } \\
\text { coordinate }\end{array}$} & \multirow{2}{*}{$\begin{array}{l}\text { AWOS } \\
\text { station }\end{array}$} & \multicolumn{2}{|c|}{$\begin{array}{l}\text { AWOS station } \\
\text { coordinate }\end{array}$} & \multirow{2}{*}{$\begin{array}{l}\text { Horizontal } \\
\text { distance } \\
(\mathrm{m})\end{array}$} & \multicolumn{2}{|c|}{$\begin{array}{l}\text { Station height } \\
\text { (m) }\end{array}$} \\
\hline & $\begin{array}{l}\text { Longitude } \\
\text { (deg.) }\end{array}$ & $\begin{array}{l}\text { Latitude } \\
\text { (deg.) }\end{array}$ & & $\begin{array}{l}\text { Longitude } \\
\text { (deg.) }\end{array}$ & $\begin{array}{l}\text { Latitude } \\
\text { (deg.) }\end{array}$ & & GNSS & AWOS \\
\hline ABUZ & 7.65 & 11.15 & Zaria & 7.68 & 11.10 & 6855.03 & 705.05 & 655.00 \\
\hline
\end{tabular}

To apply GNSS for meteorological purposes, it is necessary to scale down the Zenith Tropospheric Delay (ZTD) into its constituent fractions; the zenith hydrostatic delay (ZHD) and zenith wet delay (ZWD). The ZHD is majorly accountable for the ZTD ( 90\% using experimental models with given surface temperature and pressure). The ZWD is of meteorological importance, due to its significant relationship with humidity changes both spatially and temporally. The PWV can be derived from ZWD as described by Bevis et al. (1994) in Equation [2]. 


$$
P W V=\frac{10^{6}}{R_{W} \rho_{W}\left(K_{2}^{\prime}+K_{3} / T_{m}\right)} \times(Z T D-Z H D)
$$

$\rho_{w}$ - water density; $R_{w}$ - water vapour specific gas constant $\left\{461.525 \pm 0.003\left[\mathrm{~J} \mathrm{~kg}^{-1} \mathrm{~K}^{-1}\right]\right\} ; k_{2}^{\prime}$ and $k_{3}$ [refraction constants in $\mathrm{K} \mathrm{mb}^{-1}\left(22.1 \pm 2.2 \mathrm{~K} \mathrm{mb}^{-1}\right.$ and $\left.373900 \pm 0.012\right)$ ]; $T_{m}$ - weighted mean temperature in troposphere gauged in Kelvin; $P W V$ - precipitable water vapour

The mean temperature $\left(T_{m}\right)$ utilized for the extraction of the PWV estimate is described in Equation [3] below.

$$
T_{m}=\left(T_{0}-\beta H\right)\left[1-\frac{\beta R}{g_{m} \lambda^{\prime}}\right]
$$

$T_{o}, \beta$ and $\lambda$ are meteorological parameters; $H$ - orthometric height in metres; $\lambda^{\prime}=\lambda+1$ (unit less); $R$ is the gas constant for dry air $\left(287.054 \mathrm{Jkg}^{-1} \mathrm{~K}^{-1}\right) ; g_{m}$ - gravity acceleration at the atmospheric column centroid in $\mathrm{ms}^{-2}$.

Applying Saastamoinen (1972) model for the ZHD constituent and meteorologically sourced global pressure temperature (GPT) model, a simplified PWV (mm) relationship to ZWD is described in Equation [4] as follows:

$$
P W V=Z W D \times\left[9.80392-\frac{16917.64}{0.053499 T_{s}+1739.07624}\right]
$$

$Z W D=$ zenith wet delay; $T_{s}$ - surface temperature measured in Kelvin

\subsection{Atmospheric Aerosol Estimates}

MODIS is the most appropriate atmospheric satellite information for investigating aerosols with proficiency for local, regional and global scale air pollution monitoring (Ali et al., 2017). It comprises of 36 spectral bands for precise observation of atmospheric heat and humidity, as well as its constituents which include aerosols and trace gases (Misra et al., 2015). The algorithm for the MODIS aerosol optical depth (AOD) retrieval is centred on the theory of recording aerosol reflectance from reflectance at atmospheric top using Rayleigh path radiance and surface reflectance. This is expressed by Wong et al. (2008) using Equation [5].

$$
\begin{aligned}
& \rho_{\text {TOA }}\left(\theta_{o}, \theta_{s}, \phi\right)= \\
& \rho_{\text {ATM }}\left(\theta_{o}, \theta_{s}, \phi, \tau_{\text {Aer }}, \tau_{\text {Ray }}, p(\theta), \omega_{o}\right)+\frac{T_{\text {Tot }}\left(\theta_{o}\right) \times T_{\text {Tot }}\left(\theta_{s}\right) \times \rho_{\text {Surf }}\left(\theta_{o}, \theta_{s}\right)}{1-\rho_{\text {Surf }}\left(\theta_{o}, \theta_{s}\right) \times r_{\text {Hem }}\left(\tau_{\text {Tot }}, g\right)}
\end{aligned}
$$


$\theta_{\mathrm{o}}$ - peak slant of sun; $\theta_{\mathrm{s}}$ - peak slant of satellite; $\phi$ - clockwise horizontal slant from meridian; $\rho(\theta)$ phase function (angular dispersal of scattered light); $\rho_{\text {ATM }}$ - atmospheric path reflectance; $g$ - asymmetry parameter; $\tau_{\mathrm{Hem}}\left(\tau_{\mathrm{Tot}}, \mathrm{g}\right)$ - hemispheric reflectance; $\omega_{\mathrm{o}}$ - single scattering albedo; $\tau_{\mathrm{Tot}}\left(\mathrm{m}_{\mathrm{o}}\right)$ - total transmittance; $\rho_{\text {Surf }}\left(\theta_{0}, \theta_{\mathrm{s}}\right)$ - surface reflectance; $\tau_{\text {Aer, }}, \tau_{\text {Ray }}$ and $\tau_{\text {Tot }}$ - aerosol optical thickness, Rayleigh optical thickness, and overall optical thickness respectively.

The Rayleigh path radiance is obtained from Equation [6] by computing its spectral requirements and phase function, as described by Bucholtz (1995).

$$
\tau_{R a y}(\lambda)=P \times \lambda^{-(Q+R \lambda+S / \lambda)} \times \frac{p(z)}{p_{o}}
$$

where $\mathrm{P}, \mathrm{Q}, \mathrm{R}, \mathrm{S}$ are the standard atmospheric aggregate of Rayleigh scattering cross-section plus volume scattering coefficients while $\mathrm{p}(\mathrm{h})$, the appropriate height pressure is defined in Equation [7].

$$
p(h)=p_{o} \times \exp \left[\frac{-29.87 \times g \times 0.75 \times h}{8.315 \times\left(T_{S}-g \times 0.75 \times h\right)}\right]
$$

Where $\mathrm{h}$ - altitude from digital elevation model; $\mathrm{g}$ - acceleration due to gravity and $\mathrm{T}_{\mathrm{s}}-$ surface temperature

For the MODIS aerosol estimates, the deep blue level 3 version 5.1 aerosol products (http://disc.sci.gsfc.nasa.gov/SSW/\#keywords=MYD08_D3 5.1) was adopted for its geophysical parameter, averaged into $\left(-90.0^{\circ}\right.$ to $\left.+90.0^{\circ}\right)$ latitude and $\left(-180.0^{\circ}\right.$ to $\left.+180.0^{\circ}\right)$ longitude grid cells (Tian et al., 2014). The variable [Deep_Blue_Aerosol_Optical_Depth_Land_Mean] takes convenience of the dark-exterior attributes at $0.47 \mu \mathrm{m}$ blue wavelengths and frail dust penetration at $0.65 \mu \mathrm{m}$ red wavelength (Shi et al., 2013; Misra et al., 2015). The downloaded MODIS precipitable water vapour variable (IR retrieval) datasets were accessed using Panoply software (Vollmer, 2010). The subset MODIS $_{\mathrm{AOD}}$ and MODIS $\mathrm{PWV}_{\mathrm{P}}$ estimates were then collocated over the ABUZ station using the Kriging interpolation mechanism (Araki et al., 2015; Li et al., 2016).

\subsection{Ground Particulate Measurements}

The use of efficient portable sensors for particulate matter $\left(\mathrm{PM}_{10}\right)$ measurements is getting major attention across the globe (Liu et al., 2014; Li and Biswas, 2017). The study utilized the validated Chinaway CW-HAT200 particulate counter, to obtain ground samples measurements for $\mathrm{PM}_{10}$ in (microgram per meter cube, $\mu \mathrm{g} \mathrm{m}^{-3}$ ) using the laser diode principle. The sample measurements were collected for the duration of 1 year (1 December 2015 - 30 November 2016) and collocated with the 
available daytime averaged ABUZ GPS Pwv $_{\text {and }}$ MODIS ${ }_{\mathrm{AOD}}$ estimates. Instrument background and pump flow was also examined prior to conducting each measurement session. The portable $\mathrm{PM}_{10}$ instrument were validated using the WHO air filter sampling technique, described in Efe and Efe (2008). The validation results are displayed in Figure 3.

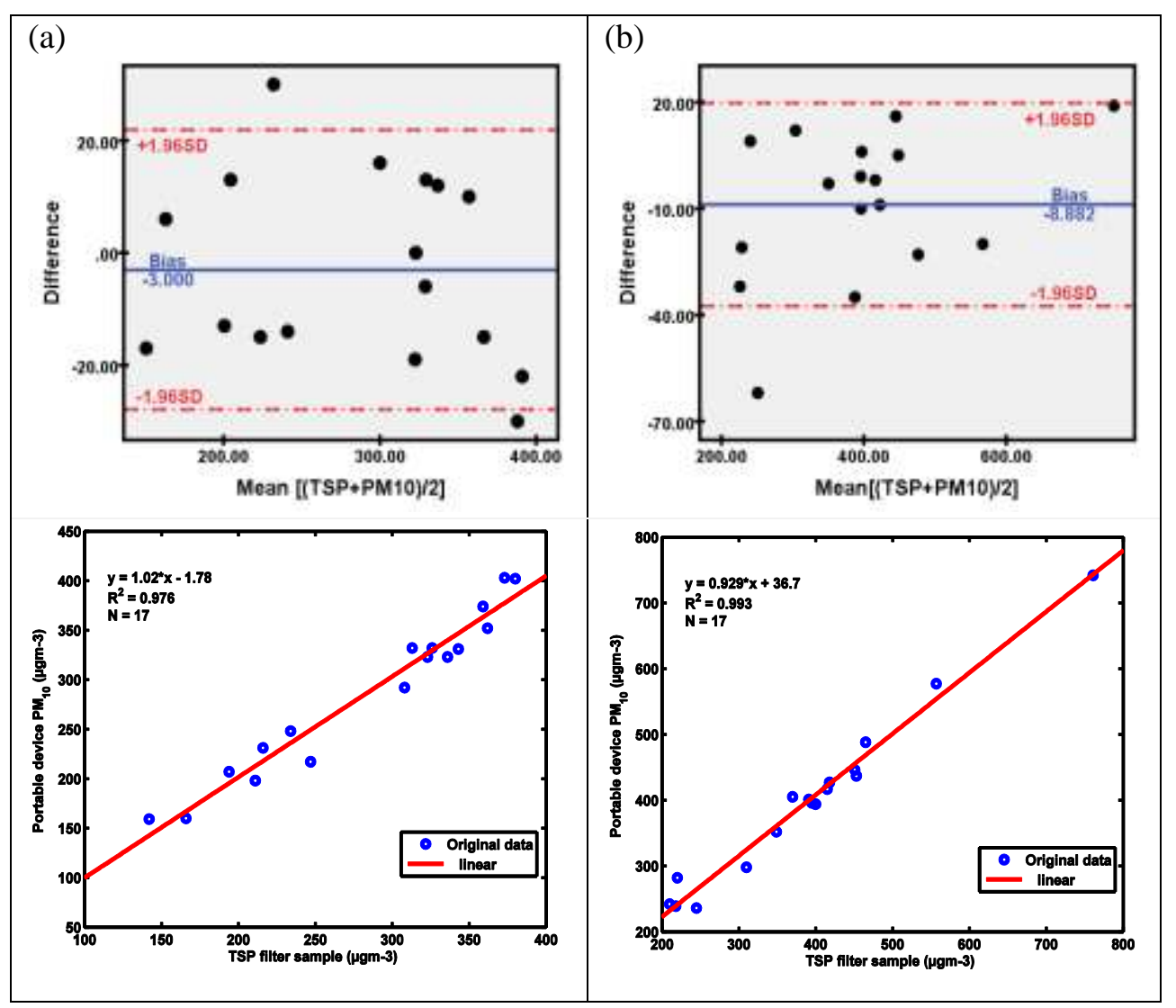

Figure 3. Agreement and linear regression plots showing the bias and coefficient of determination between the TSP and the CW-HAT200 particulate monitor samples at two sample sites (a) control site, (b) dense activity site (modified after Aliyu and Botai, 2018)

\subsection{Data Analysis Approach}

The study is interested in evaluating the effects of atmospheric aerosols and ground particulates concentrations on GPSPwv estimates. Figure 4 highlights the flowchart which describes the steps taken to achieve this study. The datasets utilized in this study covered a duration of 1-year (December 2015 - November 2016). 


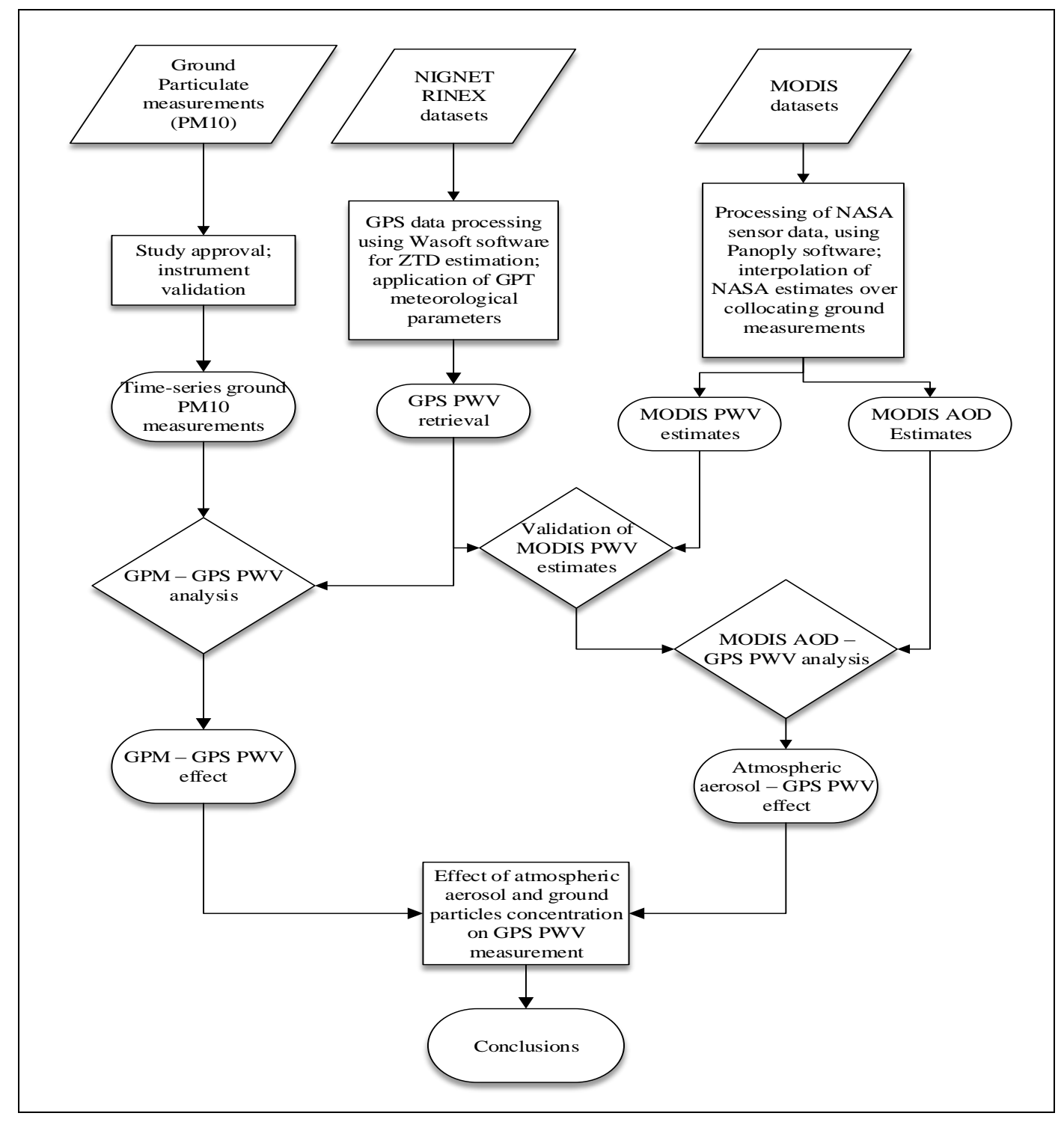

Figure 4. Flowchart of the data analysis steps

The assimilation process for aerosol estimation using GPS-derived PWV estimates involves three empirical steps (Equation 1 - 3). First, we determined the ZTD. It is the GNSS signal attenuation primarily responsible for indicating precipitable water vapour contents (Bevis et al., 1994; Rohm et al., 2014). Second, we utilized the GPS meteorology concept. This extracts the precipitable water vapour (PWV) from the GPS-ZTD estimates given that the atmospheric temperature and pressure at the ABUZ station is known (Isioye et al., 2017). Finally, we utilized literatures which indicated that water vapour takes out aerosol from the atmosphere that usually occur as a result of particulate matter (PM) floating in the air/gas or dissolved in water. PM are a major contributor of aerosol constituents in the troposphere from which the PWV is derived using the GPS ZTD signal (Lau and He, 2017). It has been established that PWV and particulates (aerosols) have a significant inverse relationship (Gui et al., 2017a). Furthermore, the degree of relationship between the PM and AOD quantities have established by literature. Their relationship can be determined using their level of correlation (Schäfer et al., 2008; 
Yap and Hashim, 2013). This practical approach is acknowledged for examining PM concentration from satellite remote sensing AOD data. A full data processing technique for relating PM with AOD is discussed in Filip and Stefan (2011).

To ensure reliability of our results, we adopted four performance indicators to evaluate the GPSderived PWV estimates for aerosol monitoring. The indicators include: alpha data reliability (Le Boennec and Salladarré, 2017), correlation coefficient (R) (Murphy, 1988) and root mean square error (RMSE) (Chai and Draxler, 2014). They are represented mathematically in Equations [8 - 10]. The alpha data reliability index computes the average factor by which observed measurements of interest differ from one another. The correlation ( $\mathrm{R}$ ) weighs the level of variability in the actual values that is explained by the model. RMSE expresses the difference between observations predicted by a model.

$$
\begin{gathered}
\alpha=\frac{N \cdot \bar{C}}{\bar{v}+(N-1) \cdot \bar{C}} \\
R=\frac{\left.\sum_{i=1}^{n}\left(P_{i}-\bar{P}\right)\left(O_{i}-\bar{O}\right)\right)}{\left[\sum_{i=1}^{n}\left(P_{i}-\bar{P}\right)^{2} \times \sum_{i=1}^{n}\left(O_{i}-\bar{O}\right)^{2}\right]^{\frac{1}{2}}} \\
R M S E=\left[\frac{1}{n} \sum_{i=1}^{n}\left(O_{i}-P_{i}\right)^{2}\right]^{\frac{1}{2}}
\end{gathered}
$$

where $\mathrm{N}$ is the sample size, $\mathrm{c}$ is average covariance between the GPS $\mathrm{PWv}_{\mathrm{Pw}}$ estimates $\left(\mathrm{O}_{\mathrm{i}}\right)$ and the predicting MODIS $\mathrm{PWV}_{\mathrm{P}}$ and MODIS $\mathrm{AOD}_{\text {estimates }}\left(\mathrm{P}_{\mathrm{i}}\right), \vartheta$ is the average variance, $\mathrm{O}_{\mathrm{i}}$ is time series of reference GPS PWv $_{\text {estimates, }} \mathrm{P}_{\mathrm{i}}$, is the time series of predicted MODIS $\mathrm{PWV}_{\text {and }}$ MODIS ${ }_{\mathrm{AOD}}$ models, $\bar{O}$ and $\bar{P}$ denotes the averages of the reference and predicted model values; $\mathrm{N}$ indicates number of observation samples.

\section{Results and Discussion}

The distribution of the GPS-derived PWV (GPSPwV) estimates over the ABUZ station was

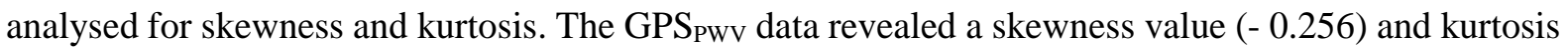
value (-1.509). The standard error across the GPS GPS-derived PWV estimates were normal distributed with the 95\% confidence interval. To further certify the assumption of normality, the Shapiro-Wilk's test based on an empirical standardization of

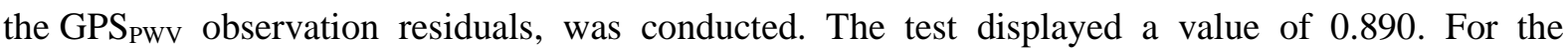
MODIS $_{\mathrm{PWV}}$, the value for skewness and kurtosis is -0.312 and -1.426 respectively. The Shapiro-Wilk's 
test of the MODIS PWv $_{\text {observation residuals is } 0.882 \text {. These results did conclude that the GPS }}$ observations are normally distributed. Figure 5 illustrates the time-series data of the collocating average PWV estimates from the ABUZ and MODIS instruments for the time interval (1300 - $1415 \mathrm{~h})$. The time series data revealed varying data breaches for the collocating observations. While the data gap for the ABUZ station is restricted to hardware issues, he MODIS breaches is as a result of the LanceMODIS latency plus hardware issues.

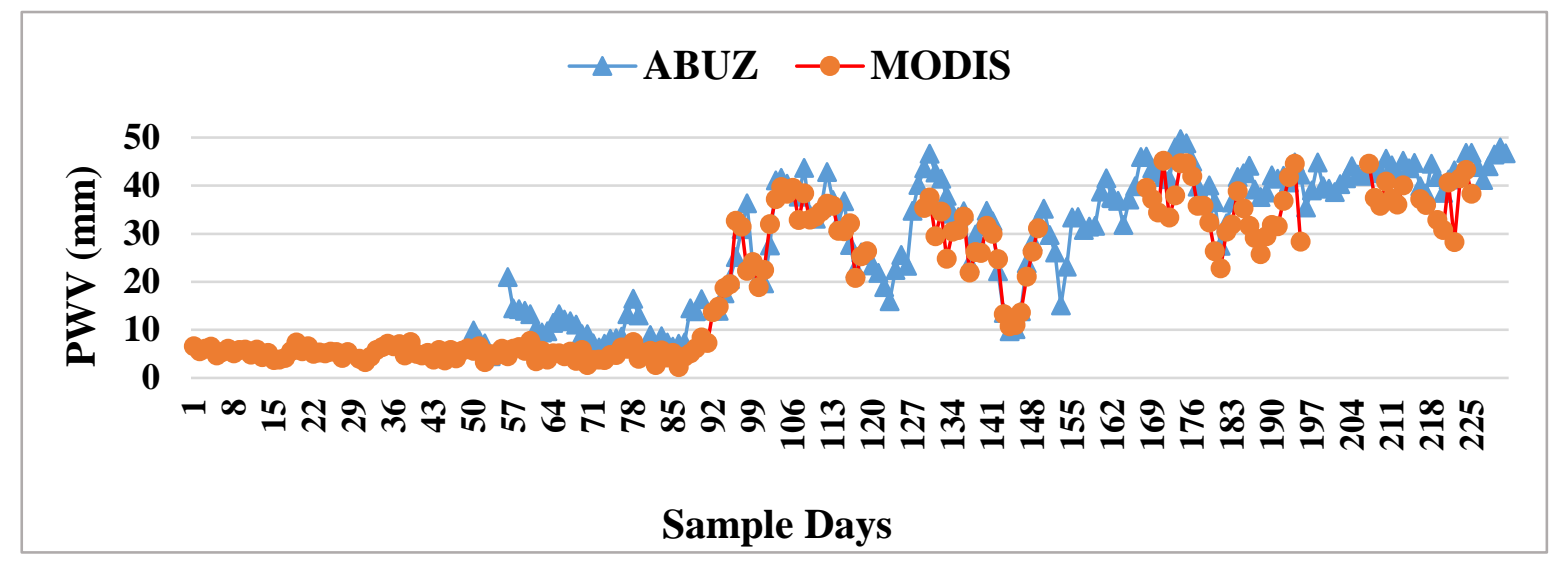

Figure 5. Time series of collocating average PWV from the ABUZ station and MODIS instrument for the study period (available sample days' equals 232)

\subsection{Effects of MODIS $S_{A O D}$ concentrations on $G P S_{P W V}$}

Prior to the GPS PWV-MODIS $_{\mathrm{AOD}}$ investigation, we conducted a pre-validation of the MODIS instrument (MODIS ${ }_{\mathrm{PWV}}$ ) using the GPS PWv $_{\text {measurements. The MODIS }}$ Pwv estimates were extracted from the MODIS MYD08_D3 5.1 IR retrieval variable. We utilized available GPS Pwv $_{\text {data }}$ for the study period. The available datasets were categorized the data across seasons; December-January-February (DJF), March-April-May (MAM), June-July-August (JJA) and September-October-November (SON). The time-analysis in Figure 5 showed that MODIS ${ }_{P W V}$ recorded good correlating estimates when

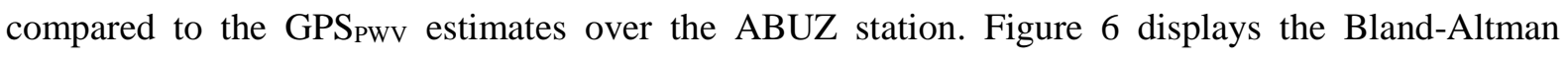
agreement plot, linear regression and boxplots of the compared PWV residuals. The daily average PWV $(\mathrm{mm})$ recorded across the collocated stations ranged from (4.60 - 49.66) and (2.25 - 45.09) for GPS and MODIS instrument respectively (Figure 6b). 

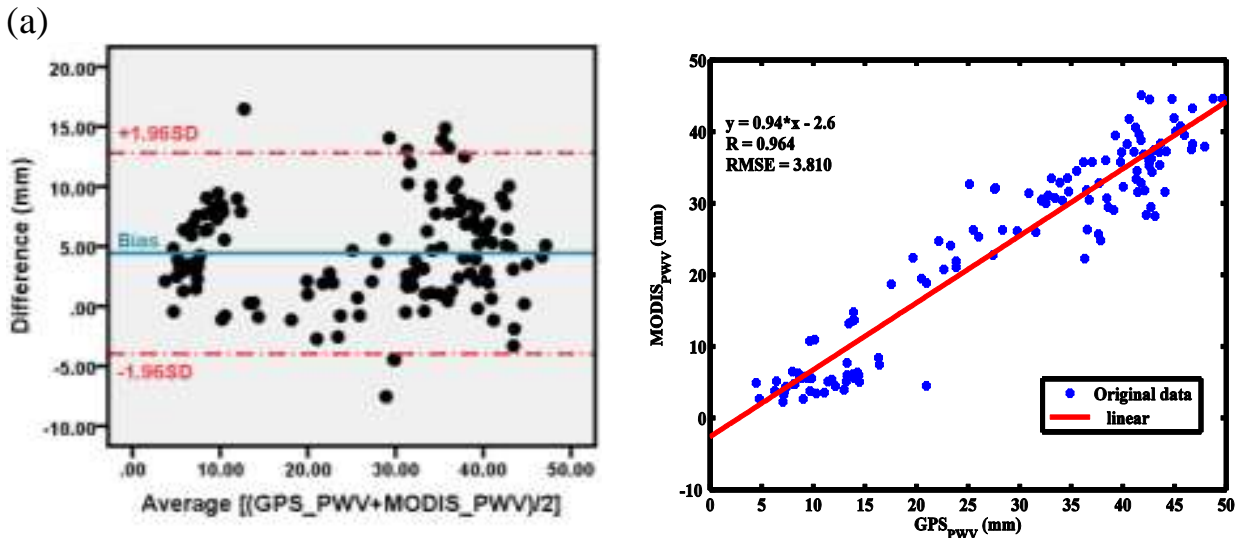

(b)
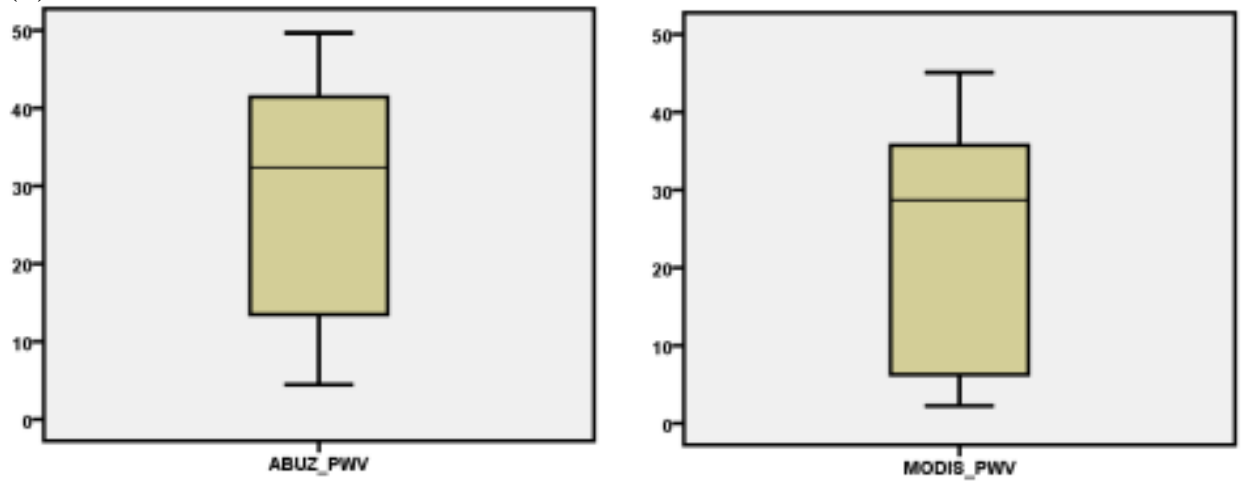

Figure 6. (a) Difference - linear regression plot of the GPS ${ }_{P W V}$ and MODIS ${ }_{P W v}$ estimates (b) Boxplots showing the range of PWV values

The GPS data acquisition process revealed that there were no available datasets for SON season.

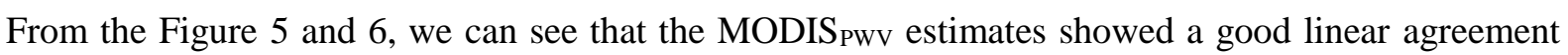
with GPS $S_{P W V}$ estimates. Table 2 illustrates the GPS $S_{P W V}-M O D I S_{P W V}$ validation results. The descriptive revealed good GPS $_{\mathrm{PWV}}-\mathrm{MODIS} \mathrm{PWv}_{\mathrm{P}}$ agreement at surface level $(\mathrm{R}=0.96$; $\mathrm{RMSE}=3.81)$. This MODIS $_{\mathrm{PWV}}$ validation is within the range of acceptable results, when compared to similar research findings on PWV validation (Tsidu et al., 2015; Gui et al., 2017b) but slightly lower than Ningombam et al., (2016). From Table 2, we can also conclude that the computed alpha reliability, correlation coefficient, root mean square error and bias, were within the range of PWV estimation with GPS positioning.

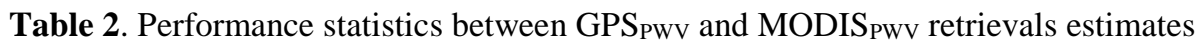

\begin{tabular}{ccccccc}
\hline GPS station & Season & $\alpha$ & & R & RMSE (mm) & Bias (mm) \\
\cline { 6 - 7 } \cline { 5 - 6 } ABUZ & DJF & 0.98 & 0.77 & 1.03 & 5.46 \\
& MAM & 0.99 & & 0.93 & 3.42 & 2.94 \\
& JJA & 0.98 & 0.79 & 3.95 & 6.49 \\
& Combined & 0.97 & 0.96 & 3.81 & 4.41 \\
\hline
\end{tabular}


To determine the effect of MODIS ${ }_{\mathrm{AOD}}$ concentrations on GPS $\mathrm{PWV}_{\mathrm{PV}}$ estimates, MODIS $\mathrm{AOD}_{\mathrm{A}}$ estimates was collected over the ABUZ station collocating with the GPS Pwv estimates for the study period. The MODIS ${ }_{\mathrm{AOD}}$ measurement over the ABUZ station, was obtained after the initial spatial boundary box sub-setting and subsequent Kriging interpolation described in Aliyu and Botai (2018). The descriptive statistics of the MODIS ${ }_{\mathrm{AOD}}$ estimates over the ABUZ station showed that the standard error of mean ranged from 0.04. The standard error of skewedness and kurtosis were computed as 0.17 and 0.34 respectively. The Shapiro-Wilk's test of normality (0.83) also indicated that the estimates are normally distributed over the ABUZ station. All the collocating data observations (GPS PWv $_{\text {and }}$ MODIS $\left._{\mathrm{AOD}}\right)$ indicated strong reliability $(\alpha>0.90)$ over the ABUZ station. Figure 7 displays the timeseries of the MODIS ${ }_{\mathrm{AOD}}$ measurements against the GPS $\mathrm{PWV}_{\mathrm{P}}$ estimates.

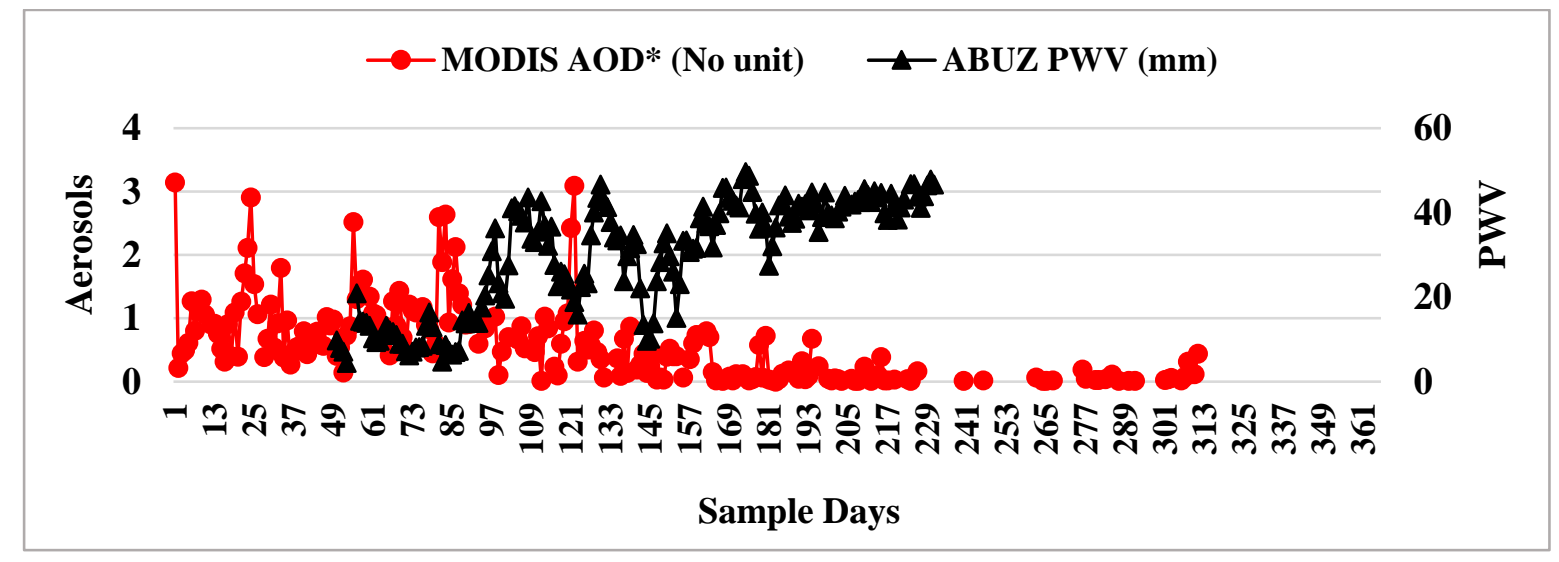

Figure 7. Time-series of the collocating averaged GPS $_{\mathrm{PWV}}$ estimates and MODIS $\mathrm{AOD}_{\mathrm{A}}$ measurements

The GPS PWv $_{\text {and }}$ MODIS ${ }_{\mathrm{AOD}}$ measurements were significant $(\mathrm{p}<0.05)$. The GPS $\mathrm{PWv}_{\mathrm{P}}$ and MODIS $_{\mathrm{AOD}}$ analysis showed good correlation performance $(\mathrm{R} \leq-0.64)$ with the JJA season recorded the better performance $(\mathrm{R}=-0.79 ; \alpha=0.999 ; \mathrm{RMSE}=0.46)$. Our finding for the GPS $\mathrm{PWV}_{-}-\mathrm{MODIS}_{\mathrm{AOD}}$ analysis does agree with Gui et al. (2017a) that evaluated atmospheric aerosol (AOD) with PWV estimates from radiosondes and weather stations.

\subsection{Effects of GPM Concentrations on GPS $S_{P W V}$}

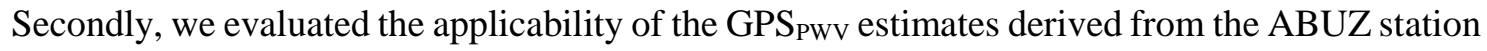
for monitoring ground particulate matter (GPM) measurements. We utilized the available collocating

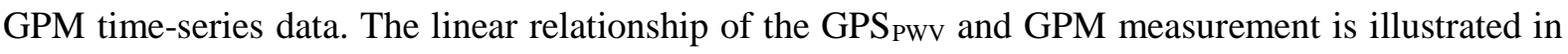
Figure 8. Table 3 also displays the descriptive statistics of the collocating GPM measurements. 


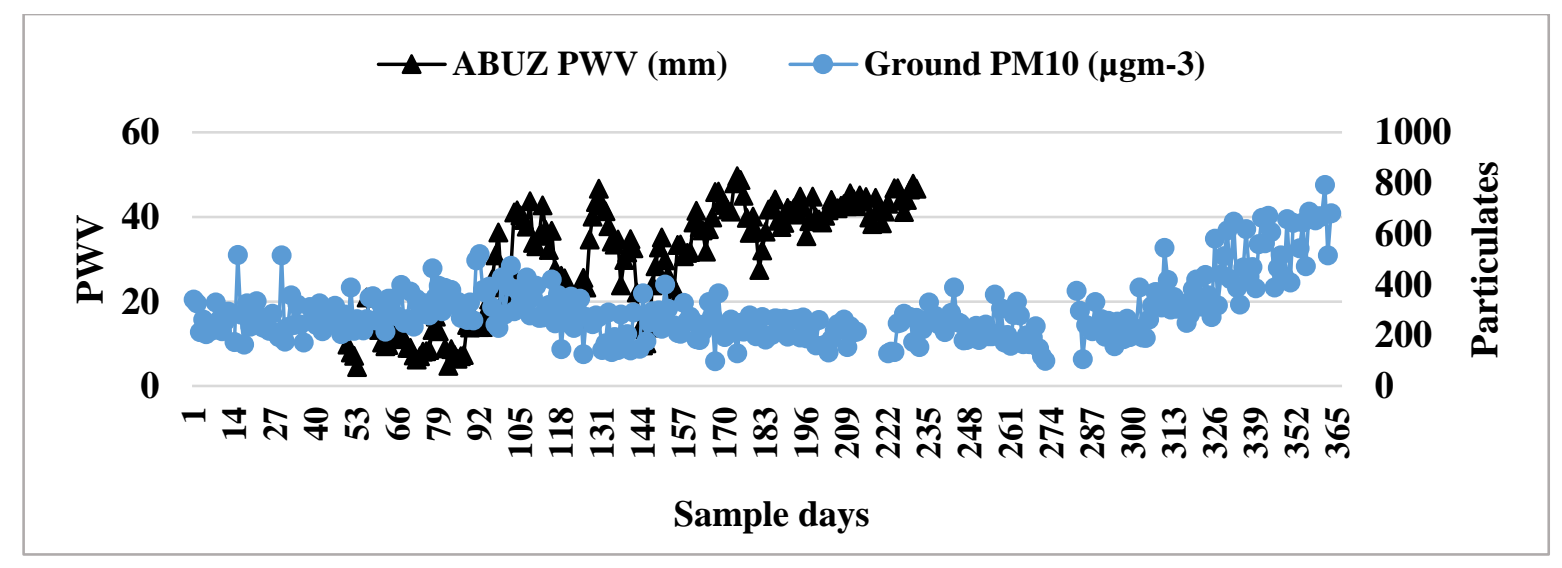

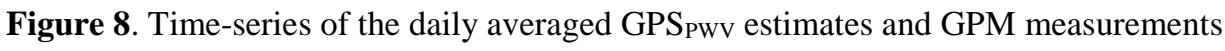

In Table 3, we can see that the probabilities of datasets normality are greater than 0.05 , thus the null hypothesis $\left(\mathrm{H}_{0}\right)$ is accepted. This indicates that the datasets are normal distributed as well as within satisfactory skewness and kurtosis. Also, the MAM and JJA season recorded higher GPM concentrations. This could be attributed to the massive construction activities that commenced within the study area.

Table 3. Descriptive statistics of collocating GPM measurements

\begin{tabular}{lccc}
\hline Season & DJF & MAM & JJA \\
\hline Mean $\left(\mu \mathrm{g} \mathrm{m}^{-3}\right)$ & 309.08 & 300.94 & 224.01 \\
SE of mean & 12.24 & 10.99 & 9.71 \\
SD & 127.25 & 114.30 & 100.90 \\
Skewness & 1.12 & 0.49 & 0.167 \\
Kurtosis & 1.28 & -0.12 & -1.01 \\
Shapiro-Wilk's Test & 0.92 & 0.97 & 0.97 \\
\hline
\end{tabular}

For the comparative results of the GPM concentrations against the GPS PWV $_{\text {estimates. The }}$

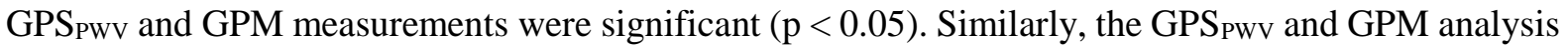
showed good correlation $(\mathrm{R})$ range of values $(-0.66,-0.67$ and -0.79$)$ for the DJF, MAM and JJA

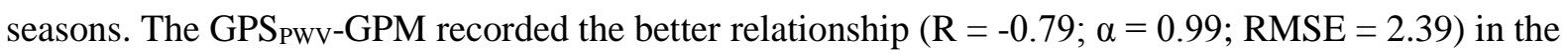

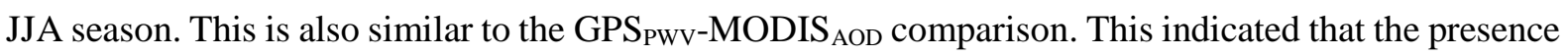
of ground level particulates resulting from anthropogenic activities contributes significantly, to atmospheric aerosol concentration within the study area. There are very limited studies that analysed

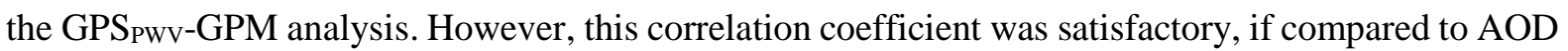
- $\mathrm{PM}_{10}$ study $(\mathrm{R}=-0.70)$ reported by Filip and Stefan (2011). Furthermore, the GPS investigation can contribute to the position accuracy for similar related studies in the future. 
From the above-described results, we can conclude that the prediction of MODIS AOD and particulate matter, $\mathrm{PM}_{10}$ from GPS $\mathrm{Pwv}$ estimations, does provide convincing argument for the study

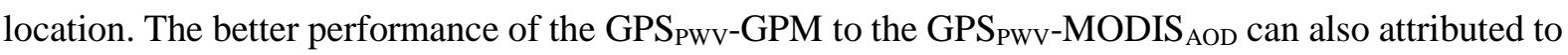
the alternating humidity and cloud across the study seasons, as it may impact negatively on the MODIS retrievals thus responsible for observation variations.

\section{Conclusions}

With the World Health Organization reporting alarming particulate pollution level across Nigerian cities, this paper presents seasonal variability of the input parameters; GPS-derived precipitable water vapour, MODIS AOD estimates and ground PM measurements over Zaria, Nigeria for December 2015 - November 2016. We examined the effect of atmospheric aerosols and ground particulate matter concentrations on GPS derived precipitable water estimates. The collocating datasets utilized for this study revealed satisfactory results for skewness and normality. The MODIS-GPS prevalidation procedure results showed good agreement for GPS PwV-MODIS $_{\mathrm{PWV}}$ across the instruments.

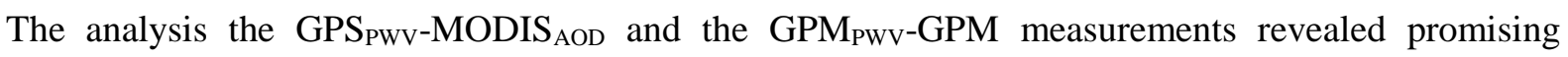
relationships which were similar to related studies. The spatial variability of particulates/aerosols concentration within the Nigerian territory cannot be ignored, thus the need to explore available operational techniques for efficient pollution monitoring. Our study introduced a novel physical mechanism of the GPS PWV-PM relationship that can be utilized for future position accuracy. The incorporation of our findings will provide a basis for the improved analysis of the aerosol/particulates processes. These findings present an applicability of the Nigerian GNSS Reference Network (NIGNET) for monitoring ground particulates and satellite aerosol measurements. Thus, the Nigerian air pollution planners can begin to consider its NIGNET stations for aerosol monitoring, taking into consideration its limited air pollution monitoring capabilities.

\section{Acknowledgements}

We acknowledge the National Aeronautic Space Agency (NASA) for the daily level 3 data MODIS AOD and the Office of the Surveyor General of the Federal Republic of Nigeria (OSGOF) for GNSS observation data. This study is supported by the University of Pretoria postgraduate bursary and the Ahmadu Bello University, Zaria research grant to the first author. We are grateful the anonymous reviewers for helping to improve the manuscript. Finally, we thank Olalekan Isioye for assisting with the WaSoft processing. 


\section{References}

Abbasy, S., Abbasi, M., Asgari, J., Ghods, A., 2017. Precipitable water vapour estimation using the permanent single GPS station in Zanjan, Iran. Meteorological Applications 24(3), 415-422. https://doi.org/10.1002/met.1639

Ali, M.A., Assiri, M., Dambul, R., 2017. Seasonal aerosol optical depth (AOD) variability using satellite data and its comparison over Saudi Arabia for the period 2002-2013. Aerosol and Air Quality Research 17(5), 1267-1280. https://doi.org/10.4209/aaqr.2016.11.0492

Aliyu, Y.A., Botai, J.O., 2018. Appraising city-scale pollution monitoring capabilities of multi-satellite datasets using portable pollutant monitor. Atmospheric Environment 179, 239-249. https://doi.org/10.1016/j.atmosenv.2018.02.034

Araki, S., Yamamoto, K., Kondo, A., 2015. Application of regression kriging to air pollutant concentrations in Japan with high spatial resolution. Aerosol and Air Quality Research 15, 234241. https://doi.org/10.4209/aaqr.2014.01.0011

Ayorinde, T.T., Rabiu, A.B., Amory-Mazaudier, C., 2016. Inter-hourly variability of total electron content during the quiet condition over Nigeria, within the equatorial ionization anomaly region. Journal of Atmospheric and Solar-Terrestrial Physics 145, 21-33. https://doi.org/10.1016/j.jastp.2016.04.005

Bai, Z., Feng, Y., 2003. GPS water vapour estimation using interpolated surface meteorological data from Australian automatic weather stations. Journal of Global Positioning System, 2(2), 83-89.

Bevis, M., Businger, S., Herring, T.A., Rocken, C., Anthes, R.A., Ware, R.H., 1992. GPS meteorology: Remote sensing of atmospheric water vapor using the Global Positioning System. Journal of Geophysical Research 97, 15787-15801. https://doi.org/10.1029/92JD01517

Bevis, M., Businger, S., Chiswell, S., Herring, T.A., Anthes, R.A., Rocken, C., Ware, R.H., 1994. GPS meteorology: mapping zenith wet delays onto precipitable water. Journal of Applied Meteorology 33(3), 379-386. https://doi.org/10.1175/1520-0450(1994)033<0379:GMMZWD>2.0.CO;2

Bonafoni, S., Biondi, R., 2016. The usefulness of the Global Navigation Satellite Systems (GNSS) in the analysis of precipitation events. Atmospheric Research 167, 15-23. https://doi.org/10.1016/j.atmosres.2015.07.011

Bucholtz, A., 1995. Rayleigh-scattering calculations for the terrestrial atmosphere. Applied Optics 34(15), 2765-2773. https://doi.org/10.1364/AO.34.002765

Boehm, J., Werl, B., Schuh, H., 2006. Troposphere mapping functions for GPS and very long baseline interferometry from European centre for medium-range weather forecasts operational analysis data. Journal of Geophysical.Research. B: Solid Earth 111(2), B02406. https://doi.org/10.1029/2005JB003629

Boutiouta, S., Lahcene, A., 2013. Preliminary study of GNSS meteorology techniques in Algeria. International Journal of Remote Sensing 34(14), 5105-5118. https://doi.org/10.1080/01431161.2013.786850

Chai, T., Draxler, R.R., 2014. Root mean square error (RMSE) or mean absolute error (MAE)? arguments against avoiding RMSE in the literature. Geoscience Model Development 7(3), 12471250. https://doi.org/10.5194/gmd-7-1247-2014 
Chew, B.N., Campbell, J.R., Hyer, E.J., Salinas, S.V., Reid, J.S., Welton, E.J., Holben, B.N., Liew, S.C., 2016. Relationship between aerosol optical depth and particulate matter over Singapore: effects of aerosol vertical distributions. Aerosol and Air Quality Research 16, 2818-2830. https://doi.org/10.4209/aaqr.2015.07.0457

Duncan, B.N., Prados, A.I., Lamsal, L.N., Liu, Y., Streets, D.G., Gupta, P., Hilsenrath, E., Kahn, R.A., Nielsen, E., Beyersdorf, A.J., Burton, S.P., Fiore, A.M., Fisherman, J., Henze, D.K., Hosteltler, C.A., Krotkov, N.A., Lee, P., Lin, M., Pawson, S., Pfister, S., Pickering, K.E., Bradley Pierce, R., Yoshida, Y., Ziemba, L.D., 2014. Satellite data of atmospheric pollution for US air quality applications: examples of applications, summary of data end-user resources, answers to FAQs, and common mistakes to avoid. Atmospheric Environment 94, 647-662. https://doi.org/10.1016/j.atmosenv.2014.05.061

Efe, S.I., Efe, A.T., 2008. Spatial distribution of particulate matter (PM10) in Warri metropolis, Nigeria. The Environmentalist 28(4), 385-394. http://doi.org/10.1007/s10669-007-9154-0

Filip, L., Stefan, S., 2011. Study of the correlation between the near-ground PM10 mass concentration and the aerosol optical depth. Journal of Atmospheric and Solar-Terrestrial Physics 73(13), 18831889. https://doi.org/10.1016/j.jastp.2011.04.027

Gui, K., Che, H., Chen, Q., Zeng, Z., Zheng, Y., Long, Q., Sun, T., Liu, X., Wang, Y., Liao, T., Yu, J., 2017a. Water vapour variation and the effect of aerosols in China. Atmospheric Environment 165, 322-335. https://doi.org/10.1016/j.atmosenv.2017.07.005

Gui, K., Che, H., Chen, Q., Zeng, Z., Liu, H., Wang, Y., Zheng, Y., Sun, T., Liao, T., Wang, H., Zhang, X., 2017b. Evaluation of radiosonde, MODIS-NIR-Clear, and AERONET precipitable water vapor using IGS ground-based GPS measurements over China. Atmospheric Research 197, 461-473. https://doi.org/10.1016/j.atmosres.2017.07.021

Gupta, P., Christopher, S.A., Wang, J., Gehrig, R., Lee, Y.C., Kumar, N., 2006. Satellite remote sensing of particulate matter and air quality over global cities. Atmospheric Environment 40(30), 58805892. https://doi.org/10.1016/j.atmosenv.2006.03.016

Isioye, O.A., Combrinck, L., Botai, J.O., 2017. Retrieval and analysis of precipitable water vapour based on GNSS, AIRS, and reanalysis models over Nigeria. International Journal of Remote Sensing 38(20), 5710-5735. https://doi.org/10.1080/01431161.2017.1346401

Kouba, J., 2009. A Guide to Using International GNSS Service (IGS) Products. http://acc.igs.org/UsingIGSProductsVer21.pdf, accessed in August 2017.

Lau, L., He, J., 2017. Investigation into the effect of atmospheric particulate matter (PM2. 5 and PM10) concentrations on GPS signals. Sensors 17(3), 508. https://doi.org/10.3390/s17030508

Le Boennec, R., Salladarré, F., 2017. The impact of air pollution and noise on the real estate market. The case of the 2013 European green capital: Nantes, France. Ecological Economic 138, 82-89. https://doi.org/10.1016/j.ecolecon.2017.03.030

Li, J., Biswas, P., 2017. Optical characterization studies of a low-cost particle sensor. Aerosol and Air Quality Research 17(7), 1691-1704. https://doi.org/10.4209/aaqr.2017.02.0085

Li, S., Ma, Z., Xiong, X., Christiani, D.C., Wang, Z., Liu, Y., 2016. Satellite and ground observations of severe air pollution episodes in the winter of 2013 in Beijing, China. Aerosol and Air Quality Research 16(4), 977-989. https://doi.org/10.4209/aaqr.2015.01.0057 
Liu, J., Man, Y., Liu, Y., 2014. Temporal variability of $\mathrm{PM}_{10}$ and $\mathrm{PM}_{2.5}$ inside and outside a residential home during 2014 Chinese spring festival in Zhengzhou, China. National Hazards 73(3), 21492154. https://doi.org/10.1007/s11069-014-1157-9

Madrigano, J., Kloog, I., Goldberg, R., Coull, B.A., Mittleman, M.A., Schwartz, J., 2013. Long-term exposure to PM2.5 and incidence of acute myocardial infarction. Environmental Health Perspective 121(2), 192-196. https://doi.org/10.1289/ehp.1205284

Middey, A., Chaudhuri, S., 2013. The reciprocal relation between lightning and pollution and their impact over Kolkata, India. Environmental Science and Pollution Research 20, 3133-3139. https://doi.org/10.1007/s11356-012-1219-z

Misra, A., Jayaraman, A., Ganguly, D., 2015. Validation of version 5.1 MODIS aerosol optical depth (deep blue algorithm and dark target approach) over a semi-arid location in Western India. Aerosol and Air Quality Research 15(1), 252-262. https://doi.org/10.4209/aaqr.2014.01.0004

Murphy, A.H., 1988. Skill scores based on the mean square error and their relationships to the correlation coefficient. Monthly Weather Reviews 116(12), 2417-2424. https://doi.org/10.1175/1520-0493(1988)116<2417:SSBOTM>2.0.CO;2

Musa, T.A., Amir, S., Othman, R., Ses, S., Omar, K., Abdullah, K., Samsung, L., Rizos, C., 2011. GPS meteorology in a low latitude region: remote sensing of atmospheric water vapour over Malaysian peninsula. Journal of Atmospheric and Solar-Terrestrial Physics 73, 2410-2422. https://doi.org/10.1016/j.jastp.2011.08.014

Ningombam, S.S., Jade, S., Shrungeshwara, T.S., Song, H.J., 2016. Validation of water vapour retrieval from moderate resolution imaging spectro-radiometer (MODIS) in near infrared channels using GPS data over IAO-Hanle, in the Trans-Himalayan Region. Journal of Atmospheric and SolarTerrestrial Physics 137, 76-85. https://doi.org/10.1016/j.jastp.2015.11.019

Nordio, F., Kloog, I., Coull, B.A., Chudnovsky, A., Grillo, P., Bertazzi, P.A., Baccarelli, A.A., Schwartz, J., 2013. Estimating spatio-temporal resolved PM10 aerosol mass concentrations using MODIS satellite data and land use regression over Lombardy, Italy. Journal of Atmospheric and Solar-Terrestrial Physics 74, 227-236. https://doi.org/10.1016/j.atmosenv.2013.03.043

Ortiz de Galisteo, J.P., Bennouna, Y., Toledano, C., Cachorro, V., Romero, P., Andrés, M.I., Torres, B., 2014. Analysis of the annual cycle of the precipitable water vapour over Spain from 10-year homogenized series of GPS data. Quarterly Journal of the Royal Meteorological Society 140, 397 406. https://doi.org/10.1002/qj.2146

Rohm, W., Yuan, Y., Biadeglgne, B., Zhang, K., Le Marshall, J., 2014. Ground-based GNSS ZTD/IWV estimation system for numerical weather prediction in challenging weather conditions. Atmospheric Research 138, 414-426. https://doi.org/10.1016/j.atmosres.2013.11.026

Saastamoinen, J., 1972. Atmospheric correction for troposphere and stratosphere in radio ranging of satellites', In the use of artificial satellites for geodesy, Henriksen, S.W., Mancini, A., Chovitz, B.H., (Eds.), vol. 15 of Geophysics Monograph Series, pp. 247-252, American Geophysical Union (AGU), AIAA, NOAA, U.S. ATC, Washington, D.C.

Schäfer, K., Harbusch, A., Emeis, S., Koepke, P., Wiegner, M., 2008. Correlation of aerosol mass near the ground with aerosol optical depth during two seasons in Munich. Atmospheric Environment 42(18), 4036-4046. https://doi.org/10.1016/j.atmosenv.2008.01.060 
Schröder, L., Richter, A., Fedorov, D.V., Eberlein, L., Brovkov, E.V., Popov, S.V., Knöfel, C., Horwath, M., Dietrich, R., Matveev, A.Y., Scheinert, M., 2017. Validation of satellite altimetry by kinematic GNSS in central east Antarctica. The Cryosphere 11(3), 1111-1130. https://doi.org/10.5194/tc-11-1111-2017

Shi, Y., Zhang, J., Reid, J.S., Hyer, E.J., Hsu, N.C., 2013. Critical evaluation of the MODIS deep blue aerosol optical depth product for data assimilation over North Africa. Atmospheric Measuring Techniques 6(4), 949-969. https://doi.org/10.5194/amt-6-949-2013

Solomon, S., Rosenlof, K.H., Portmann, R.W., Daniel, J.S., Davis, S.M., Sanford, T.J., Plattner, G.K., 2010. Contributions of stratospheric water vapour to decadal changes in the rate of global warming. Science 327, 1219-1223. https://doi.org/10.1126/science.1182488

Streets, D.G., Canty, T., Carmichael, G.R., de Foy, B., Dickerson, R.R., Duncan, B.N., Edwards, D.P., Haynes, J.A., Henze, D.K., Houyoux, M.R., Jacob, D.J., 2013. Emissions estimation from satellite retrievals: a review of current capability. Atmospheric Environment 77, 1011-1042. https://doi.org/10.1016/j.atmosenv.2013.05.051

Tian, B., Manning, E., Fetzer, E., Olsen, E., Wong, S., Susskind, J., Iredel, L., 2014. AIRS/AMSU/HSB $\begin{array}{llllll}\text { Version } & 6 & \text { Level } & 3 & \text { Product } & \text { User }\end{array}$ http://disc.sci.gsfc.nasa.gov/AIRS/documentation/v6_docs/v6releasedocs1/V6_L3_User_Guide.p df, accessed in April 2016.

Tsay, S.C., Maring, H.B., Lin, N.H., Buntoung, S., Chantara, S., Chuang, H.C., Gabriel, P.M., Goodloe, C.S., Holben, B.N., Hsiao, T.C., Hsu, N.C., 2016. Satellite-surface perspectives of air quality and aerosol-cloud effects on the environment: an overview of 7-SEAS/BASELInE. Aerosol and Air Quality Research 16, 2581-2602. https://doi.org/10.4209/aaqr.2016.08.0350

Tsidu, G.M., Blumenstock, T., Hase, F., 2015. Observations of precipitable water vapour over complex topography of Ethiopia from ground-based GPS, FTIR, radiosonde and ERA-Interim reanalysis. Atmospheric Measurement Techniques 8(8), 3277-3295. https://doi.org/10.5194/amt8-3277-2015

UNEP (United Nations Environment Programme) 2015. Fuel Quality Progress in Nigeria for Nigeria National Air Quality Management Program. Report presented by the Federal Ministry of $\begin{array}{llll}\text { Environment } & \text { on } & 18 & \text { May }\end{array}$ http://www.unep.org/Transport/new/PCFV/pdf/2015_Ecowas_FuelQualityProgress_Emmanuel.p df, accessed in October 2017.

Vollmer, B., 2010. AIRS Data and Services at the GSFC Earth Sciences Data and Information Services Centre (GES DISC). Available from: http://airs.jpl.nasa.gov/documents/science team meeting archive/2010 11/slides/Vollmer.pdf. Last access: June 2016.

Wanninger, L., 2000. Interpolation von GPS-Beobachtungen. Allg. Vermnachr. 107, 360-363.

WHO, (World Health Organization) 2016. Global Urban Ambient Air Pollution Database Update. http://www.who.int/phe/health_topics/outdoorair/databases/WHO_AAP_database_May2016_v3 web.xlsx?ua=1, accessed in September 2017.

Wong, M.S., Nichol, J., Lee, K.H., Li, Z., 2008. Retrieval of Aerosol Optical Thickness using MODIS $500 \times 500 \mathrm{~m}^{2}$, a study in Hong Kong and Pearl River Delta region. 2008 International Workshop on Earth Observation and Remote Sensing Applications. 
Yap, X.Q., Hashim, M., 2013. A robust calibration approach for PM10 prediction from MODIS aerosol optical depth. Atmospheric Chemistry and Physics 13(6), 3517-3526. https://dx.doi.org/10.5194/acpd-12-31483-2012

Zhang, H., Yuan, Y., Li, W., Ou, J., Li, Y., Zhang, B., 2017. GPS PPP- derived precipitable water vapour retrieval based on $\mathrm{Tm} / \mathrm{Ps}$ from multiple sources of meteorological data sets in China. Journal of Geophysical Research: Atmospheres 122(8), 4165-4183. https://doi.org/10.1002/2016JD026000

Zhao, P., Yin, Y., Xiao, H., Zhou, Y., Liu, J., 2016. Role of water vapor content in the effects of aerosol on the electrification of thunderstorms: A numerical study. Atmosphere 7(10), 137. https://doi.org/10.3390/atmos7100137

Zumberge, J. F., Heflin, M.B., Jefferson, D.C., Watkins, M. M., Webb, F. H., 1997. Precise point positioning for the efficient and robust analysis of GPS data from large networks. Journal of Geophysical Research 102, 5005-5017. https://doi.org/10.1029/96JB03860 